\title{
The challenges of knowledge production by researchers in Public Administration, a South African perspective
}

\author{
J. S. Wessels \\ Department of Public Administration and Management \\ University of South Africa \\ Pretoria, South Africa \\ wessejs@unisa.ac.za
}

\begin{abstract}
This article reflects on the challenges of knowledge production by researchers in South African Public Administration. It tries to establish whether published Public Administration research findings indeed address the core knowledge needs of government by solving those problems which cannot be solved by competent public officials. An analysis is, inter alia, done of (a) articles published in a South African peer-reviewed journal for Public Administration, (b) the research focus areas of the National Research Foundation (NRF), (c) the Practices for Effective Local Government developed by the International City/County Management Association (ICMA), and (d) of the address of the President of South Africa, Thabo Mbeki, at the second joint sitting of the third democratic Parliament, Cape Town on 11 February 2005. This article concludes that South African scholars in Public Administration, on the one hand, and government, on the other hand, at least have a shared awareness of what needs to be known in the field.
\end{abstract}

\section{INTRODUCTION}

Fourteen years ago the (South African) Scientific Advisory Council (SAC) published various volumes of publications resulting from its investigation into the implementation of research findings. In one of these publications, an essay 'A critique of utilitarian reason' the statement is made that the 'effects of a utilitarian culture on social theory are subtle and severe' (De Beer 1991, 241). In this essay, De Beer argues that the utilitarian culture is by no means limited to exposing social theory 'to the expectation that it has a practical usefulness'. He warns his reader that the 'social science of a utilitarian culture tends towards a theoryless empiricism' (De Beer 1991, 241). In an era when the concepts subsidy and subsidy formula have specific monetary meaning for scholars all over the spectrum of disciplines, it is essential to reflect on the effect of this utilitarian culture on one's own subject. The urge to establish the practical usefulness of a subject such as Public Administration for its object of study, namely the public sector, seems to be commonly accepted as legitimate. Some scholars, trying to be politically correct, will even call it constitutional.

One of the most prominent characteristics of the Constitution of the Republic of 
South Africa of 1996 is certainly its Bill of Rights (South Africa 1996, Chapter 2). This Bill of Rights is binding to the legislature, the executive, the judiciary and all organs of state. Public administration, in other words the 'organised, non-political, executive functions of the state' (Pauw 1995; 1999, 22) plays an important role in the state's effort to promote these constitutional rights in South Africa.

This role of public administration is fulfilled within a changing context, for example, having to cope with new legislative and policy guidelines. Consequently, public officials are confronted with new problems to be solved. These problems are by and large solved by highly skilled and experienced practitioners with a lot of common sense. However, new problems arise nearly daily and it is difficult for these competent public officials to solve these problems alone. These problems need hard-to-come by knowledge to be solved, knowledge produced through the intervention of researchers trained in one or more of the various scientific traditions. It is safe to assume that the academic subject Public Administration has to produce research results solving public administration problems which can't be solved by competent public officials alone. The subject's practical usefulness or meaning for the public sector, may have a direct influence on its ability to survive as an academic subject and scholarly community.

The purpose of this article is then to reflect on the challenges of knowledge production by researchers in South African Public Administration. I will try to establish whether published Public Administration research findings do indeed address the core knowledge needs of government by solving those problems that cannot be solved by competent public officials. For the purpose of answering these two questions, an analysis will, inter alia, be done of (a) articles published in a South African peer-reviewed journal for Public Administration, (b) the research focus areas of the National Research Foundation (NRF), (c) the Practices for Effective Local Government development by the International city/County Management Association (ICMA), and (d) of the address of the President of South Africa, Thabo Mbeki, at the second joint sitting of the third democratic Parliament, Cape Town on 11 February 2005.

\section{THE PURPOSE OF SCIENTIFIC RESEARCH IN PUBLIC ADMINISTRATION}

Before we try to establish whether research in Public Administration does address the core knowledge needs of the government in South Africa, it is perhaps appropriate to reflect for a while on concepts such as knowledge and research. Without a thorough review of the wide and very old collection of literature on knowledge and theory of knowledge, I want to restrict myself to only a few authors whose views on this topic seem to be useful for this discussion. In a book Knowing and being published as early as 1969, the philosopher Michael Polanyi refer to knowledge as 'an activity which would be better described as a process of knowing' (Polyani 1969, 132). Such a process may be research.

What is research? The Concise Oxford Dictionary defines research as '[c]areful 
search or inquiry after or for; the endeavour to discover new facts etc. By scientific study of the subject, course or critical investigation'. This definition focuses on two aspects of the concept, the process (search, inquiry, endeavour, scientific study, critical investigation) and the goal (discovery of new facts and principles) (Wessels 1999, 363). Leedy especially agrees with the latter part of the definition by stating that research has one prime goal, namely discovery (Leedy 1993, 8). The definition by Bless and Higgson-Smith focuses on both parts, namely the process of 'translation into practice of the relationship between facts and theory' and the goal of 'acquiring knowledge' (Bless and Higgson-Smith 1995, 12). Mouton elaborates on the goal of research by stating that the "predominant purpose of all research is to arrive at results that are as close to the truth as possible, i.e. the most valid findings possible' (Mouton 1996, 28). Polanyi (1969, 132) reminds the reader that both knowledge and research are also on the move 'according to similar principles, towards a deeper understanding of what is already known'.

Research, the endeavour to discover new facts and principles, as stated by the Oxford Concise Dictionary, can be regarded as a typical human activity. As Babbie formulates it, research is a 'native human activity' (Babbie 1992, 4). On the other hand, science is commonly regarded, not as a natural human process, but a tradition whose constituent rules of conduct are not fully explicated (Pauw 1996, 67). This implies that not all research activities and results can be regarded as science (Wessels 1999, 364). As Pauw points out, it is possible for something to have the characteristics which are expected of scientific work - to be rational, systematic, and objective - but still not be part of science (Pauw 1996, 66). The implication of this argument is that an investigation can be done by means of a method that has originated in science (eg surveys), but still not be part of science (Wessels 1999, 364).

Without having to embark on an extended discussion on the question of what research is, one can argue that if research is a human activity to acquire knowledge, scientific research is probably a conditioned human activity to acquire new and valid scientific knowledge about a specific field of study. It seems that the distinction between survey type of research and scientific research lies in the substance of the product of the investigation - the type of knowledge (Wessels 1999, 364).

I believe that not all knowledge is part of science; in other words, not all inquiries by means of methods originated in science lead to scientific knowledge. The telephone directory giving exact (rational, systematic and objective) information about the telephone number of a specific individual, is an appropriate example. The fact that the statement about the telephone number of a specific individual is true, that objective evidence exists about it, and that the user of the service believes that it is true, does not imply that the knowledge about the telephone number is scientific.

However, science needs scientific research. As Mouton puts it, 'The acceptance or rejection of scientific statements is based on the outcome of ongoing research' 
(Mouton 1996, 13). Without research, no new and valid scientific knowledge will be generated. Thus, the scientific face of research distinguishes itself from other types of investigation (its non-scientific face) by generating new and valid scientific knowledge. In this sense, scientific research is indispensable for the existence of Public Administration as a field of scientific knowledge (Wessels 1999, 364-365). Baehler et al. (2005, 43), a group of New Zealand researchers, make a distinction in this regard between academic research and research that is linked directly to policy development, in other words, practice.

A series of articles (published over more than a decade) in the Public Administration Review, initiated by McCurdy and Cleary in 1984, debates specifically the quality of research in Public Administration. Although these articles focus predominantly on the methodological dimension of research, it is the quality - in other words, the outcome of the research effort - that concerns them the most. It seems that they are concerned that research in Public Administration does not contribute to the knowledge base of the subject. For example, Perry and Kraemer see it as a concern about 'the degree to which research is adding to a variable knowledge base that we can use to improve public administration as an applied science' (Perry and Kraemer 1986, 216). This concern is shared by Wright, Manigault and Black $(2004,747)$ who are of the opinion that Public Administration is obligated to 'advance theoretical and pragmatic understanding of government institutions and processes'. This understanding requires the generation of new knowledge through research (Wright et al. 2004, 747).

Most academics in Public Administration will probably agree with the view by Bolton and Stolcis $(2003,627)$ that it is often difficult to fit real-world problems and settings into the scientific method. They refer in their article to Buckley's five areas of tension existing between the needs of scholars and those of practitioners (Buckley 1998, 4),

- Theoretical versus pragmatic

- Data-supported versus logic

- Scientific method versus case examples and common sense

- Academic-oriented versus practitioner-oriented journals

- Tenure versus organisational effectiveness.

These tensions are presumably inherent to the applied nature of Public Administration, which lead to valid concerns that researchers in Public Administration may be not busy with activities of science and that they may be not contributing to scientific knowledge. Furthermore, these concerns imply that research on problems and issues relating to professional practice may be not scientific (Wessels 1999, 366).

What then are the so-called 'activities of science'? Adams and White answer that it is research that 'contribute[s] to theory' (Adams and White 1994, 567). To be of any theoretical significance, research in Public Administration should, 
according to Stallings, 'rise above the individual and particular problems of day-today practical administration' (Stallings 1986, 239). Some authors argue that it should address the central problems in the field (Box 1992, 62). But who decides what problems are central in the field of Public Administration? The fact that the answer to this question is not so obvious is confirmed by Baily when he refers to the 'issue' of what are the questions of central importance to the field of public administration (Baily 1992, 48).

Are the problems at the core of the field of Public Administration the same as the core knowledge needs of the government of a specific country? Houston and Delevan hold the opinion that Public Administration at least 'lacks a broad theoretical framework or paradigm to guide and inspire scholars' (Houston and Delevan 1990, 679). If they are correct, it means that researchers in Public Administration do need the guidance of practice (government) to determine their research priorities and foci. Is this perhaps guidance towards 'theoryless empiricism' (De Beer 1991, 234)? I will continue this discussion in the next section.

Public Administration research indeed is supposed to be something different from general survey research. It is not supposed only to give a systematic description of a problem in practice with some practical solutions for it. A good practitioner with systematic thinking skills can do that too (compiling a telephone directory). Issues for a researcher in Public Administration are those which are not solvable by a practitioner with systematic thinking skills. Such issues are usually explained or solved by concepts, theories, and paradigms within the subject Public Administration (Wessels 1999, 367). Perry and Kraemer refer to these issues as 'core issues' in the subject (Perry and Kraemer 1986, 221).

The solving of core issues brings us to another statement and its implication for Public Administration by De Beer, namely that we can hope for a decisive progress of knowledge only if, parallel to the intensification of our ability to do good quality research, we relate equally to a necessary metadiscourse responding to the question of the meaning of our subject (De Beer 1991, 241). The existence of Public Administration as a distinct subject, point to a utilitarian relationship with its main object of study, namely public administration, the public sector, or government. Government is not only the study object of Public Administration research, but in most cases also 'consumer' of the research results. One of the implications of this relationship is that the government is also the main sponsor of Public Administration research, not only in South Africa, but also other countries such as New Zealand and Australia (Baehler et al. 2005, 44). Streib, Slotkin and Rivera confirm the existence of a need for reliable knowledge about the public sector which are perhaps broader that the utilitarian one, by referring to the researchers which have been drawn to public administration since the early 1900s out of a desire to address the problems of government and society (Streib et al. 2001, 515). 
The main purpose of scientific research is thus to explore, describe, explain or even understand the central problems or core issues of the field of study. Research within Public Administration should not be the exception.

\section{A PROFILE OF ISSUES RESEARCHED BY PUBLIC ADMINISTRATION SCHOLARS IN SOUTH AFRICA}

The bulk of the research output of South African Public Administration scholars can be found in dissertations, theses and articles in scientific journals. It is also a common practice to publish the major research findings of dissertation and thesis research in accredited scientific journals. What are the main research issues of published research findings in South African Public Administration? For the purpose of this article I have selected the (South African) Journal of Public Administration to analyse articles for establishing a South African profile of Public Administration research issues. The Journal of Public Administration, already in its 40th volume, is the oldest and most established accredited journal for South African scholars in Public Administration. I have also decided to select only the last five full volumes of the journal for analysis. All 115 articles published in volumes 35 to 39 have been analysed in order to determine the issue or theme of the research conducted for each article.

How will one determine the core issues? There may be various ways of doing it. One way of determine these issues is to follow the criteria used by McCurdy and Cleary $(1984,50)$,

- Did the research explicitly strengthen or weaken an existing theory or establish conditions under which the theory operates?

- Was the topic or issue under study central to the field of public administration?

Their criterion in this regard is whether the general theme or issue of the article warrants at least a few pages of treatment in leading textbooks on Public Administration. These criteria may perhaps work in the United States of America. However, these criteria will not be a solution in South Africa as it will instigate a whole debate on which textbooks can be regarded as 'leading'. One may also ask whether core issues in the United States, the origin of most of the leading textbooks on Public Administration, and South Africa are the same.

I have decided to categorise them according to the eleven main categories of the proposed unit standards for Public Administration and Management (SGB, Online). Choosing the proposed unit standards (see Table 1) poses to be a safe middle ground as most of the academic and practice stakeholders participated in its proceedings and agreed to some extent on the framework and content. 
Table 1: Categories of unit standards for Public Administration and Management

1 Policy Analysis \& Management (POL)

2 Development Management (DEV)

3 Public Organisational Development \& Management (ODM)

4 Managing public service delivery (PSD)

5 Human Resources Management (HRM)

6 Financial Management \& Procurement (FMP)

7 Information, Knowledge, Communication \& Technology Management (ICT)

8 Public Management Ethics (ETH)

9 Public Administration and Management history, theory and research (HTR)

10 Disaster Studies (DIS)

11 Inter-Governmental Relations (IGR)

This categorisation reveals the following profile (Table 2 and Figure 1) of research issues or categories reported in the Journal of Public Administration in the period 2000-2004:

Table 2: Profile of research issues reported in the Journal of Public Administration (JoPA) in the period 2000-2004

\begin{tabular}{|l|r|r|c|}
\hline Categories & No & Per cent & Priority \\
\hline 1 Policy Analysis \& Management (POL) & 12 & 13,80 & 5 \\
2 Development Management (DEV) & 8 & 9,20 & 7 \\
3 Public Organisational Development \& Man- & 14 & 16,10 & 2 \\
agement (ODM) & 17 & 19,55 & 1 \\
4 Managing public service delivery (PSD) & 14 & 16,10 & 2 \\
5 Human Resources Management (HRM) & 6 & 6,90 & 10 \\
6 Financial Management \& Procurement (FMP) & & & \\
7 Information, Knowledge, Communication \& & 14 & 16,10 & 2 \\
Technology Management (ICT) & 9 & 10,35 & 6 \\
8 Public Management Ethics (ETH) & 4 & 4,60 & 11 \\
9 Public Administration and Management & & \\
history, theory and research (HTR) & 0 & 0,00 & 12 \\
10 Disaster Studies (DIS) & 9 & 10,35 & 6 \\
11 Inter-Governmental Relations (IGR) & 8 & 9,20 & 7 \\
12 Do not fit in any of the above & 115 & 100 & \\
Total: &
\end{tabular}


Bearing in mind that the purpose of scientific research in a subject such as Public Administration is to explore, describe, explain or even understand the central problems or core issues of the field of study, the above-mentioned categorisation of articles revealed at least the collective view on core issues of the scholars contributing to this particular journal. Table 2 shows that 82 per cent of the articles are spread fairly equally over the five most popular categories. These articles focused on issues relating to the management of public service delivery (19,55 per cent), the management or development of public institutions or organisations (16,1 per cent), human resource management in the public sector (16,1 per cent), the management of information, knowledge, communication and technology in the public sector (16,1 per cent) and policy analysis and policy (13,8 per cent). This universum of articles does not contain any contribution on disaster studies, and only 4 (4,6 per cent) on history, theory or research issues within the subject. The relatively low percentage of articles focusing on Public Administration as a subject, theory and methodology, is an early indication of a possible bias towards practice or application and a possible theoryless empiricism.

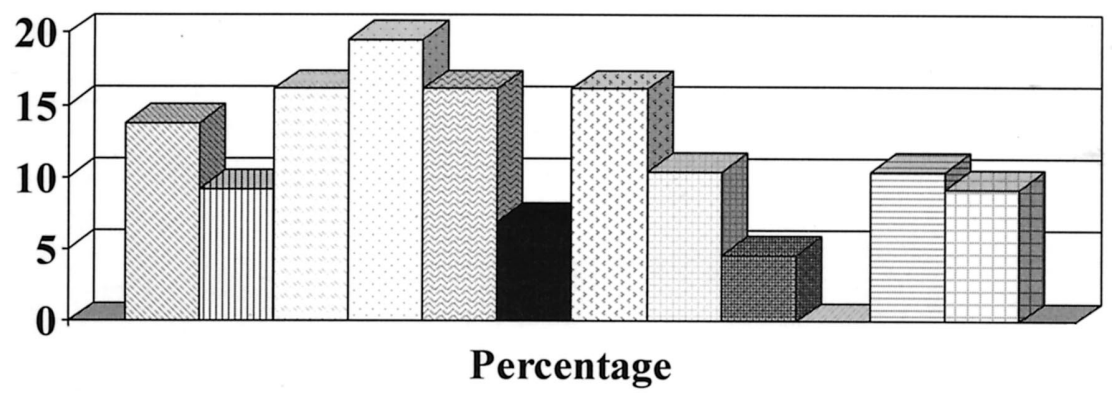

\begin{tabular}{|c|c|}
\hline$\square$ Policy analysis \& Management & Development Management \\
\hline$\square$ Public Org. Dev. \& Managnt & $\square$ Managing public service delivery \\
\hline 圆 Human resource management & - Financial Manag \& Procurement (FMP) \\
\hline ICT Management & $\square$ Public Management Ethics \\
\hline 圖 PAM History, theory \& Research & $\square$ Disaster Studies \\
\hline 曰Inter-governmental Relations & $\square$ Other \\
\hline
\end{tabular}

Figure 1: Research issues reported in JoPA: 2000-2004

It was not possible to categorise eight $(9,2$ per cent) of the articles. These articles covered issues relating to the subject Public Administration such as urban restructuring, in-migration, the effects of globalisation for the public sector, and democratic imperatives for municipal government, as well as issues not directly related to Public Administration such as industrial strategy, corporatist regimes, informal political economy and federalism in Nigeria. 


\section{THE CORE KNOWLEDGE NEEDS OF THE SOUTH AFRICAN GOVERNMENT}

Taking into consideration the issues or topics of the articles published in the Journal of Public Administration, one does not have a choice but to agree with Wamsley $(1996,363)$ that Public Administration is not a 'traditional or typical academic discipline of the social science variety'. Public Administration is indeed an 'applied interdisciplinary field', as he called it (Wamsley 1996, 364). This subject has drawn researchers in various countries since the early 1900s to address the 'applied' problems of government and the public service (Streib et al. 2001, 515).

It is the subject's applied nature that poses a challenge of a special kind to researchers. It is the challenge of choosing between (a) applying their skill of connoisseurship (Polanyi 1958, 54-55) to identify issues of central importance to the field, on the one hand, and (b) following the priorities set by the government and the public service of the specific country, on the other hand.

Edwards $(2005,68)$ makes the observation that there is often an uneasy relationship between researchers and policy practitioners who both have different perspectives on what the problem is, and unrealistic expectations of each other. For example, in New Zealand it is common for politicians and officials to bemoan the so-called irrelevance of the research being funded by public expenditure (Baehler et al. 2005, 43). The same occurs in the United Kingdom where David Blunkett, (then) Secretary of State for Education and Employment in the UK, expressed his government's frustration about the research fraternity's seeming inability to deal with issues 'which are central and directly relevant to the political and policy debate' (Blunkett 2000). According to him researchers 'fail to take into account the reality of many people's lives when identifying the research questions' (Blunkett 2000). The South African situation is no different and doesn't deviate from this trend as politicians and officials also seem to doubt the value of the contribution by the Public Administration academic community (Mwanza 2005, 11).

Bearing in mind the applied nature of the subject, it is would do good to take note of the suggestion by Baehler et al. $(2005,58)$ to consider an understanding of government priorities, including the best possible assessment of future government priorities. Reviewing the core knowledge needs of the South African government, is also not an easy task. The South African government consists of institutions on the national, provincial and local levels of government. Each of them have different knowledge needs. An example of separate research focus areas for local government is the Practices for Effective Local Government Management, developed by members of the International City/County Management Association (ICMA), namely -

- Staff effectiveness

- Policy facilitation

- Service-delivery management

- Strategic leadership 
- Democratic responsiveness

- Organisational planning and management

- Communication

- Integrity

These practices represent the best thinking of the international city management profession about the knowledge and skills required of an effective local government manager. These practices can simultaneously serve as research focus areas for researchers in local government affairs (Streib et al. 2001, 515). The overlap of the ICMA focus areas with the unit standard categories and the research preferences of South African scholars, is illustrated in Table 3.

Table 3: Comparison of ICMA focus areas with the SGB unit standard categories and the research priorities of the Journal of Public Administration

\begin{tabular}{|c|c|c|}
\hline ICMA focus areas & Unit standards categories & $\begin{array}{l}\text { Research } \\
\text { priorities }\end{array}$ \\
\hline Staff effectiveness & $\begin{array}{l}\text { Human Resources Management } \\
\text { (HRM) }\end{array}$ & 2 \\
\hline Policy facilitation & Policy Analysis \& Management (POL) & 5 \\
\hline $\begin{array}{l}\text { Service-delivery manage- } \\
\text { ment }\end{array}$ & Managing public service delivery (PSD) & 1 \\
\hline Strategic leadership & $\begin{array}{l}\text { Public Organisational Development } \\
\text { and Management (ODM) }\end{array}$ & 2 \\
\hline $\begin{array}{l}\text { Democratic responsive- } \\
\text { ness }\end{array}$ & - & 0 \\
\hline $\begin{array}{l}\text { Organisational planning } \\
\text { and management }\end{array}$ & $\begin{array}{l}\text { Public Organisational Development } \\
\text { and Management (ODM) }\end{array}$ & 2 \\
\hline Communication & $\begin{array}{l}\text { Information, Knowledge, Communi- } \\
\text { cation and Technology Management } \\
\text { (ICT) }\end{array}$ & 2 \\
\hline Integrity & Public Management Ethics (ETH) & 6 \\
\hline
\end{tabular}

The ICMA focus areas 'strategic leadership' and 'organisational planning and management' both fit into the unit standard category 'public organisational development and management' (ODM). It was not possible to get an equivalent category for the ICMA focus area 'democratic responsiveness' - a category which is regarded by the Mpumalanga Legislator as a strategic objective (Mpumalanga Provincial Legislature 2005, 15). On the other hand, the unit standard categories 'development management' (DEV), 'financial management and procurement' (FMP), 'public administration and management history, theory and research' (HTR), 'disaster studies' (DIS) and 'inter-governmental relations' (IGR) were 
seemingly not covered by the ICMA focus areas. A positive aspect of the overlap is that with the exception of intergovernmental relations, the seven categories received the highest research preferences by the South African Public Administration scholars and are covered by the ICMA focus areas. One can conclude in this regard that there is a high correlation between the existing research priorities by South African Public Administration scholars and the ICMA focus areas.

However, if one is looking for the national core knowledge needs of the South African government, two sensible pointers are perhaps the Address of the President of South Africa, Thabo Mbeki, at the Second Joint sitting of the third Democratic Parliament, Cape Town, on 11 February 2005, and the research focus areas of the National Research Foundation (Online, 15 August 2005). For the purpose of analysing the aforementioned speech by the President of the Republic of South Africa, the categories used for categorising research issues in the Journal of Public Administration were applied. As the speech also contains possible research priorities for other scientific subjects, only those which may be researched by Public Administration scholars have been identified. This analysis reveals the following (table 4) possible knowledge needs of the government or issues to be researched.

Table 4: Knowledge needs of the South African government according to speech of President Mbeki

\begin{tabular}{|c|c|c|}
\hline $\begin{array}{l}\text { Unit standards } \\
\text { category }\end{array}$ & $\begin{array}{l}\text { Current re- } \\
\text { search priority }\end{array}$ & Knowledge needs of government \\
\hline $\begin{array}{l}\text { Managing pub- } \\
\text { lic service deliv- } \\
\text { ery (PSD) }\end{array}$ & 1 & $\begin{array}{l}1 \text { The improvement of the quality of life of all people (access to } \\
\text { potable water; housing subsidies to the poor; education; social } \\
\text { wage to the poor) } \\
2 \text { The implementation/improvement of the social sector pro- } \\
\text { gramme (running water, sanitation, electricity) } \\
3 \text { The improvement of infrastructure (transport logistics, electricity and } \\
\text { water resources, liberalisation of telecommunications industry) } \\
4 \text { Increasing the capacity of local government to provide services to } \\
\text { society at large } \\
5 \text { Mobilising the public service to speed up social transformation } \\
6 \text { An assessment of the implementation of the various pro- } \\
\text { grammes of action } \\
7 \text { A review of performance practices in state-owned enterprises } \\
8 \text { Improving monitoring and evaluation across government } \\
9 \text { Establishing the reasons for the delay in implementing of some } \\
\text { programmes } \\
10 \text { The Batho Pele programme }\end{array}$ \\
\hline $\begin{array}{l}\text { Development } \\
\text { Management } \\
\text { (DEV) }\end{array}$ & 7 & $\begin{array}{l}1 \text { Properly focused development planning } \\
2 \text { Sector development strategies and programmes } \\
3 \text { Expanding public works programme } \\
4 \text { Community participation in programmes such as the Early } \\
\text { Childhood Development Programme }\end{array}$ \\
\hline
\end{tabular}




\begin{tabular}{|c|c|c|}
\hline $\begin{array}{l}\text { Unit standards } \\
\text { category }\end{array}$ & $\begin{array}{l}\text { Current re- } \\
\text { search priority }\end{array}$ & Knowledge needs of government \\
\hline $\begin{array}{l}\text { Human Resource } \\
\text { Management } \\
\text { (HRM) }\end{array}$ & 2 & $\begin{array}{l}1 \text { Increasing the number of skilled workers } \\
2 \text { Improving the effectiveness of the skills development structures in } \\
\text { government for the implementation of the Human Resources } \\
\text { Development Strategy } \\
3 \text { Increasing the number of Community Health Workers (training } \\
\text { standards, increased resources) } \\
4 \text { Ensure effective leadership of the public service: review skills and } \\
\text { levels of competence } \\
5 \text { Expanding employment in the public service } \\
6 \text { Review gender balance }\end{array}$ \\
\hline $\begin{array}{l}\text { Policy Analysis } \\
\text { and Manage- } \\
\text { ment (POL) }\end{array}$ & 5 & $\begin{array}{l}1 \text { Review of the regulatory framework as it applies to small, } \\
\text { medium and micro-enterprises } \\
2 \text { Broader understanding of society: social structure and social } \\
\text { mobility, demographics and dynamics; social organization }\end{array}$ \\
\hline $\begin{array}{l}\text { Public Organi- } \\
\text { sational Devel- } \\
\text { opment and } \\
\text { Management } \\
\text { (ODM) }\end{array}$ & 2 & $\begin{array}{l}1 \text { Interventions in the area of education and training (eg merger of } \\
\text { institutions of higher education) } \\
2 \text { Revamping SADC management structures }\end{array}$ \\
\hline $\begin{array}{l}\text { Public Manage- } \\
\text { ment Ethics } \\
\text { (ETH) }\end{array}$ & 6 & $\begin{array}{l}1 \text { Plans against corruption } \\
2 \text { Negligence and tardiness in public service }\end{array}$ \\
\hline $\begin{array}{l}\text { Inter-govern- } \\
\text { mental Rela- } \\
\text { tions (IGR) }\end{array}$ & 6 & $\begin{array}{l}1 \text { Improve integration among all spheres of government in both } \\
\text { policy development and implementation (Inter-Governmental } \\
\text { Relations Bill) }\end{array}$ \\
\hline
\end{tabular}

The emphasis on public service delivery corresponds with the research priorities of Public Administration scholars (Table 2). The preceding analysis of the speech of the President of the Republic of South Africa (Table 4) reveals a considerable overlap of issues of importance for the government-of-the-day and research preferences by Public Administration scholars. Needs were identified in seven of the possible eleven categories. The only major discrepancy is the absence of knowledge needs in the category 'Information, knowledge, communication and technology management' which shared the second popular position with two other categories in the Journal of Public Administration.

The research focus areas of the National Research Foundation (NRF) has been identified by the Research and Innovation Support Agency (RISA) of the National Research Foundation (National Research Foundation, Online). Collectively they provide a broad framework for researchers across the spectrum of disciplines (the natural, social and human sciences, engineering and technology) to pursue their research interests, taking into account the macro-environment as well as relevant national developments. These focus areas represent the South African government's macro research priorities. RISA will financially support only research within these broad focus areas which are much broader than the field of Public Administration. Consequently, if Public Administration scholars want to receive 
financial support for their research from the NRF, they need to align their research with these macro government priorities. The NRF focus areas for research are as follows (National Research Foundation, Online),

- Challenge of globalisation, perspectives from the global South (including, theorising the global; identities, movements and social change; state, society and conflict resolution; political economy and technology)

- Conservation and management of ecosystems and biodiversity

- Distinct South African research opportunities (including, palaeontology and archaeology; Southern skies; geological heritage; societies in transformation; cultural heritage and identity formation; health; creative arts and cultural expression)

- Economic growth and international competitiveness (including, technologies for competitiveness; management for competitiveness; management of the enterprise; human resources)

- Education and the challenges for change (including, restructuring in higher education, further education and training; policy implementation studies; science, technology and mathematics education; human resource development - teacher education and development; curriculum, pedagogy and assessment; language issues and literacy; HIV/AIDS in education)

Indigenous knowledge systems (including, production, transmission and utilisation of indigenous knowledge and technology; role of IK in nation building; IK at the interface with other systems of knowledge)

- Information and communication technology (ICT) and the information society in South Africa (including, software development and integration; telecommunications and networking; human-information interactions; ICT driven development)

- Sustainable livelihoods, the eradication of poverty (including, environment and natural resources utilisation; integrated food security, nutrition and health; local development; understanding the informal sector; social institutions and networks; service provision and management)

- Unlocking the future, advancing and strengthening strategic knowledge

It is obvious from the above list of research focus areas that Public Administration issues are conflated with various other issues in the social sciences and even the natural sciences. Is it possible to identify government priorities for Public Administration research from the above list? I believe that it is. Specific issues to be solved by Public Administration scholars alone should, however, be seen as subordinate to these broad focus areas. These focus areas, however, invites Public Administration researchers to start focusing on issues that need the theoretical competence of more than one subject to be solved. The challenge for Public Administration scholars is, thus, to start thinking of and participating in transdisciplinary research projects. The suggested categorisation of Public Administration research categories in terms of the NRF focus areas, are as in table 5, 
Table 5: Suggested categorisation of Public Administration research categories in terms of the NRF focus areas

\begin{tabular}{|c|c|}
\hline NRF focus area & Public Administration research categories \\
\hline Challenge of globalisation & $\begin{array}{l}\text { Issues related to policy analysis and management } \\
\text { Issues related to inter-governmental relations }\end{array}$ \\
\hline $\begin{array}{l}\text { Conservation and management of } \\
\text { ecosystems and biodiversity }\end{array}$ & No obvious Public Administration research issues \\
\hline $\begin{array}{l}\text { Distinct South African research } \\
\text { opportunities }\end{array}$ & No obvious Public Administration research issues \\
\hline $\begin{array}{l}\text { Economic growth and international } \\
\text { competitiveness }\end{array}$ & $\begin{array}{l}\text { Issues related to Public Organisational Development } \\
\text { and Management } \\
\text { Issues related to Human Resource Management } \\
\text { Issues related to Financial Management and Procure- } \\
\text { ment }\end{array}$ \\
\hline $\begin{array}{l}\text { Education and the challenges for } \\
\text { change }\end{array}$ & $\begin{array}{l}\text { Information, Knowledge, Communication and Tech- } \\
\text { nology Management } \\
\text { Policy analysis and Management }\end{array}$ \\
\hline Indigenous knowledge systems & No obvious Public Administration research issues \\
\hline $\begin{array}{l}\text { Information and communication } \\
\text { technology (ICT) }\end{array}$ & $\begin{array}{l}\text { Information, knowledge, communication and technol- } \\
\text { ogy management }\end{array}$ \\
\hline $\begin{array}{l}\text { Sustainable livelihoods: the eradi- } \\
\text { cation of poverty }\end{array}$ & Issues related to managing public service delivery \\
\hline $\begin{array}{l}\text { Unlocking the future: advancing } \\
\text { and strengthening strategic knowl- } \\
\text { edge }\end{array}$ & $\begin{array}{l}\text { Issues related to Public Administration and Manage- } \\
\text { ment history, theory and research }\end{array}$ \\
\hline
\end{tabular}

The need for Public Administration research generated knowledge identified in the speech of the President of the Republic of South Africa has shown a high correlation with existing research preferences of South African Public Administration scholars. The analysis of the President's address to Parliament gave much more specific indications of the South African government's need for Public Administration generated knowledge than the research focus areas of the NRF. However, with the exception of research issues relating to Public Management Ethics, Disaster Studies and Development Management, all the unit standard related research categories could be matched with the NRF research focus areas.

\section{THE CHALLENGES OF KNOWLEDGE PRODUCTION BY SOUTH AFRICAN RESEARCHERS IN PUBLIC ADMINISTRATION, AN ASSESSMENT}

What are the effects of the utilitarian social culture on Public Administration theory and knowledge production? The fact that only 4,6 per cent of the articles 
published in the last five volumes of the South African accredited Journal for Public Administration, is a clear indication of a near absence of a discourse responding to the question of the meaning of the subject. This poses a challenge to the scholars in the subject to start with a discourse about at least the usefulness of the subject as an explanatory 'tool' for practice problems. If the survival of the subject Public Administration depends on its ability to satisfy the knowledge needs of government, then it is important for scholars to, at least, ensure that their main 'asset' is functioning optimally.

Although it may seem to be nearly impossible to formulate core knowledge needs or priorities for the South African government, there exists a considerable overlap between research preferences of scholars, the focus areas identified by the ICMA, needs identified from the state of the nation address by the President of the Republic of South Africa, and the NRF research focus areas. In other words, scholars, professionals and government agree to a large extent on the broad categories for researchers to focus on. Furthermore, the NRF research focus areas are formulated broadly enough to accommodate the research interests of scholars and the needs of especially the government-of-the-day. These focus areas pose the challenge to Public Administration scholars to seek opportunities for transdisciplinary research in order to solve those type of problems which cannot be solved by the work done by one discipline alone.

Although one may conclude that published Public Administration research findings indeed address the core knowledge needs of government because the focus is on similar issues identified by government as focus areas for for example research funding, it is still not clear whether the published research findings really have solved material problems.

With regard to the utilitarian relationship with the practice of public administration, the following questions evolve, Do practitioners really know what they do not know? Do scholars know what practitioners need to know? The major challenge of knowledge production for scholars in any applied subject, is to unlock that tacit knowledge to know what they do not know, or to know what is needed to be known. Knowing the real needs for knowledge production is imperative for the exact evaluation of research results.

This article has shown that South African scholars in Public Administration and government do have at least a shared awareness of what needs to be known in the field. Whether it is the result of tacit knowledge by Public Administration scholars, or the effects a utilitarian culture, is not clear.

In this discussion Polanyi $(1969,144)$ deserves the last word, when he says, '... all knowledge is either tacit or rooted in tacit knowledge. A wholly explicit knowledge is unthinkable'. 


\section{REFERENCES}

Adams, G. B. and J. D. White. 1994. Dissertation research in Public Administration and cognate fields, an assessment of methods and quality. Public Administration Review 54 (6): 565-576. Babbie, E. 1992. The practice of social research. 6th edition. Belmont, Wadesworth.

Baehler, K., P. Callister, B. Gregory, G. Hawke, A. Ladley, B. Ryan, C. Scott, B. Stephans, A. Walker and A. Wolf. 2005. Surveying research on New Zealand government, what next? Australian Journal of Public Administration 64 (1): 43-61.

Bailey, M. T. 1992. Do physicists use case studies? Public Administration Review 52 (1): 4753.

Bless, C. and C. Higson-Smith. 1995. Fundamentals of social research methods, an African perspective. 2nd edition. Kenwyn, Juta.

Bolton, M. J. and G. B. Stolcis. 2003. Ties that do not bind, musings on the specious relevance of academic research. Public Administration Review 63 (5): 626-630.

Blunkett, D. 2000. Influence or irrelevance - Can social science improve government? Speech to a meeting convened by the Economic and Social Research Council, Swinden, and Department of Education and Employment, February, 2.

Box, R. C. 1992. An examination of the debate over research in Public Administration. Public Administration Review 52 (1): 62-69.

Buckley, M. R. 1998. The disconnect between the science and practice of management. Business Horizons March/April: 1-10.

De Beer, C. S. 1991. A critique of utilitarian reason, in Pitfalls in the research process, some philosophical perspectives, ed. C. S. de Beer. Volume 4 of the Publications related to the SAC investigation into the implementation of research findings. Pretoria, HSRC Publishers.

Edwards, M. 2005. Social Science research and public policy, narrowing the divide. Australian Journal of Public Administration 64 (1): 68-74.

Houston, D. J. and S. M. Delevan. 1990. Public Administration research, an assessment of journal publications. Public Administration Review 50:674-68.

Leedy, P. D. 1993. Practical research, planning and design. 5th edition. New York, Macmillan.

McCurdy, H. E. and R. E. Cleary. 1984. Why can't we resolve the research issue in Public Administration? Public Administration Review 44 (1): 49-55.

Mouton, J. 1996. Understanding social research. Pretoria, J.L. van Schaik Academic.

Mpumalanga Provincial Legislature. 2005. Five years strategic plan and performance plan for 2005-2009. Work document of the Provincial Legislature.

Mwanza, C. 2005. Die ystervrou gaan sweet. Finansies and Tegniek 25 Mei: 11.

National Research Foundation. 2005. Focus Areas. Available at: http//www.nrf.ac.za/ focusareas/unlock/index.stm. Downloaded on 15 August 2005.

Pauw, J. C. 1995. Wat is die verskynsel Publieke Administrasie en wat moet 'n student aan die universiteit in die vak met dieselfde naam leer? SAIPA Journal of Public Administration 30 (1): 28-52.

- 1996. Waarin lê wetenskaplikheid nou eintlik? en ander kwessies. SAIPA - Journal of Public Administration 31 (1): 57-69.

- 1999. The concept 'public administration'. In Reflective public administration, views from the South, eds. J. S. Wesels and J. C. Pauw. Cape Town, Oxford University Press.

Perry, J. L. and K. L. Kreamer. 1986. Research methodology in the Public Administration Review, 1975-1984. Public Administration Review 46 (3): 215-226.

Polanyi, M. 1958. Personal knowledge - towards a post-critical philosophy. London, Routledge and Kegan Paul.

- 1969. Knowing and being. London, Routledge and Kegan Paul. 
South Africa. 1996. Constitution of the Republic of South Africa, Act 108 of 1996.

Standards Generating Body. 2005. Standards Generating Body for Public Administration and Management (SGB, PAM) Homepage. Available at: http//www.jupmet.org.za/titles.htm. Dowmloaded on 15 August 2005.

Stallings, R. A. 1986. Doctoral programs in Public Administration, an outsider's perspective. Public Administration Review 46 (3): 235-240.

Streib, G., B. J. Slotkin and M. Rivera. 2001. Public Administration research from a practitioner perspective. Public Administration Review 61 (5): 515-523.

The Concise Oxford Dictionary of Current English. 1975. 5th edition. Oxford, Oxford University Press.

Wamsley, G. L.1996. A public philosophy and ontological disclosure as the basis for normatively grounded theorizing in Public Administration. In Refounding democratic Public Administration, modern paradoxes, postmodern challenges, eds. G. L. Wamsley and J. F. Wolf. London, SAGE.

Wessels, J. S. 1999. Public Administration Methodology, in Reflective Public Administration, views from the South, eds. J. S. Wessels and J. C. Pauw. Cape Town, Oxford University Press.

Wright, B. E., L. J. Manigault and T. R. Black. 2004. Quantitative research measurement in Public Administration, an assessment of journal publications. Administration and Society 35 (Jan, 6): 747-764. 